\title{
Forms, Functions and Values of Mbata Singing in Penti Ceremony at Tana Rata Village, Kota Komba District, East Manggarai Regency
}

\author{
Bergita Itu $^{1 *}$, Susilo Pradoko ${ }^{2}$ \\ Yogyakarta State University, Yogyakarta, Indonesia \\ *Corresponding Author,Email: itubergita@gmail.com
}

\begin{abstract}
Mbata song as the one of cultural that heritage at East Manggarai which is rich with the values and teachings for the human life. Mbata song is the ancestral heritage of the people in East Manggarai, which is always performed at traditional ceremonies at the Sa'o or one of the ceremonies who held by the government. One of the traditional ceremonies in this area is Penti Ceremony. Penti ceremony has a noble meaning beside of that as a thanksgiving to God or Mori Ndewa who is a god and ancestor of the harvest, also as a medium of reconciliation, or peace between villagers, and as the main place for the process of meaning of identity and a portrait of reality of how important is gratitude to the Creator and ancestor or Embu. There are three aspects of focus in this research, namely the form, function and values of Mbata Song in Penti Ceremony. This research is a qualitative descriptive study using by ethnographic approach and structuralism approach. Based on the results of the study, it was found that 1) The form of singing used in the Mbata Song at Penti ceremony is a solo that is sung first by mori mbo (host) and then in sako (answered) by the people involved and knows the song; 2) its function: a) as a means of ceremony and ritual, b) as the meaning for accompanying the dance and media communication, c) as a means of entertainment and d) as an educational facility for young generation; 3) its values: a) educational values, b) religious values and c) sociological values.
\end{abstract}

Keywords: Mbata Singing, Form, Function, Value

\section{INTRODUCTION}

Arts is one element of culture that cannot be separated from aspects of human life and reflects people's souls. Ethnic diversity with its culture throughout Indonesia becomes a nation's wealth that needs special attention including cultural forms supported by the community. As each ethnic group has distinctive cultural values that distinguish themselves from other ethnic groups, in its development each region has a significant role in instilling the love of the motherland and the spirit of nationalism because local cultural arts contain social values that can reflect the habits of the community, so that it will develop a robust culture of the environment.

Nowadays the appreciation of the young generations towards culture, especially traditional arts, is diminishing due to the lack of interest and opportunities to study traditional arts so that western culture tends to dominate their lifestyle. Communities in the reality of life usually view traditional singings as not only needed as mere entertainment satisfaction, but rather as a means of religious ceremonies and traditional rituals of an area. In other words, art is not just an object, but rather a critical outcome of everything that exists. The role of arts enters and engages in a concrete universe and then serves to correct the limitations of the world [4].

In a traditional song there is an element of meaning that raises the power of a communicative message. The traditional song elaborated in this study is Mbata singing in a Penti ritual ceremony. Mbata singing is one of the many cultural products of the East Manggarai community. As a cultural product, it is used as a medium of artistic expression to convey a variety of meanings about Manggarai's human life, as well as being a medium of public entertainment. Penti ceremony has a noble meaning, other than as a thanksgiving to God or Mori Ndewa who is a God figure. In anthropology, it is often called a customary or cultural hero and ancestor of the harvest, a medium of reconciliation or peace between villagers, and as the main place for the process of meaning of identity and a portrait of reality of the importance of gratitude to the creator or Mori, and ancestors or Embu.

Based on the identification of the problem above, the formulation of the problem is as follows. What are the forms of the Mbata singing in Penti ceremony? What are the functions of the Mbata song in Penti ceremony? What 
are the values of the social institutions contained in the Mbata singing? This study aims to describe the forms, functions, values of Mbata song in Penti ceremony in Tana Rata Village, Kota Komba District, East Manggarai Regency. The results of this study are expected to increase the knowledge and understanding of the people of East Manggarai about the forms, values, functions and Mbata singing in Penti ceremony and are expected to contribute to the thinking of litterateurs, culturalists, and the public. For litterateurs and culturalists, the results of the study can be used as materials for research whose results can be input in the framework of the mental-spiritual development of the young generations of East Manggarai society.

\section{DiscUSSION}

\section{Penti Ceremony}

Penti ceremony is a ritual conducted to give thanks to Mori Ndewa (God) and Embu Nusi (Ancestors) for the harvests that have been obtained by the community and it has vertical, horizontal, and social dimensions. The vertical dimension is as a thanksgiving to Mori and to the $E m b u$ as the creator (Mori Jari Agu De'de'k) who must be worshiped and glorified, as stated, respecting God as the source of life and human life" [2].

The main emphasis on the meaning of Penti is gratitude as the Ndehes and Manggarai people in general strongly believe in bonding with nature. This may be manifested in the joyful inner atmosphere when feeling grateful, peaceful, the spirit of brotherhood, and kinship [1]. Penti ceremony has a structure or consists of stages, namely Tete Ndere (Tete ndere ndau, ramba tau bhama. Bhama ka ko jawa. Ramba nunu bathe embu, bathe ine bathe ema. Kita tau ka jawa ga. ndau dhesi dhende lamba. Tete ndere. Ndera: ramba tau mbata, tako ndau mbata. (Tete Ndere is done to give thanks for eating new corn (young corn which has just been harvested from the garden). Tete Ndere is also done to tell the ancestors, Father and Mama to consume corn, play drum, Ndera then Mbata. Ndera means to play a musical instrument nggo (gong) and lamba (drum) using a small wood without singing. They are usually played by a tribal chief or anyone who can play a musical instrument as long as it is still in the traditional ceremonial atmosphere. $\mathrm{Pa}^{\prime} u$ Manu is a ritual performed to communicate and thank God and Ancestors before holding a traditional ceremony. What was prepared at the $P a^{\prime} u$ Manu event was a small chicken, a handful of rice, medium-sized stone luu (stone) often used in each of the words to store rice and ra'a manu (chicken blood) and one old bottle (tuak). Ра'u manu is done by the tribal chief. The last stage is Mbata.

\section{A. Forms of Mbata Singing}

The form of singing used in the Mbata song at Penti ceremony is a solo performed by Mori Mbo (host). There are five songs that must be sung, i.e. Ele rondo, Rogho sambi, Wolo lau, Bomba lau and Toto ro.

\section{B. Functions of Mbata Singing}

From the aspect of function, Mbata singing functions as follows.

\section{1) A means of the ceremony and ritual.}

In accordance with its etymology, ritual ceremonies can be divided into two words namely ceremony and ritual. A ceremony is an activity carried out by a group of people and has stages that are set according to the purpose of the event. While what is meant by ritual is a matter related to spiritual beliefs and beliefs with a certain goal. Situmorang concludes that the meaning of ritual ceremonies is an activity carried out by a group of people for the sake of spiritual beliefs and beliefs with a certain goal [3]. Mbata chant has a very important role in Penti ceremony without which the traditional ceremony (ritual) cannot be carried out properly. Each stage performed during the ceremony is always accompanied by songs that are sung as a medium for communication with Mori Ndewa (the God of God) and Embu Nusi (Ancestors).

\section{2) A Means for Accompanying Dance and Communication Media}

Vocal instrument music is the pulse in a dance. Music, singing, and dances are an inseparable unity. With the music that is included the song, the tempo can be adjusted in one motion, providing an atmosphere in the dance, either sad, happy, tense or angry. The singing and music accompanying the dance are used as atmosphere builders so that the atmosphere during the ceremony becomes more alive. Besides, music and singing can add excitement and enthusiasm to dancers or as a positive stimulus to dancers. Dancers so as not to be monotonous, it needs to be accompanied by music and singing, this will affect the dancers to be more excited.

Communication is a contact relationship between humans, both individuals and groups. In everyday life communication, realized or not, is part of human life itself. Humans have since been in communication with their environment [5]. Communication is an activity that contains an element of message delivery. Functioning as a means of communication is the role of the singing and musical accompaniment of the dance (Vera dance). Dance accompaniment and music have a function as a means of communication. The communication is contained in the togetherness between dancers, singers and dance accompaniments that become one unit. In Vera dance, the main actors are dancers accompanied by musicians, each of whom has an equally important role. Thus, delivery of messages between musicians, singers and dancers, who will present the dace to the audience must have been well established. Song and musical instruments of nggo (gong) and lamba (drum) are played together during penti ceremonies to accompany the Vera dance.

\section{3) Entertainment}

In a performance, the main goal is entertaining the spectators in spite of other secondary goals. Mbata singing in Penti ceremony accompanied by gong and drums functions as a means of entertainment. 


\section{4) Education for Young Generations}

In a song, especially a traditional song, it certainly has a variety of functions, meanings, values and meanings that mostly are positive. For example, the value can be discipline, mutual respect, responsibility, and so forth. These values can be used as knowledge for young generations of today.

The younger generations can also learn to appreciate the work of ancestral inventions and preserve local culture that has existed since ancient times.

\section{Values of Mbata Singing}

\section{1) Educational Values}

That value of education is contained in the first song Ele Rondo, the fourth song Bomba lau, and the fifth song Toto ro which will be explained as follows.

Table 1 Ele Rondo Mbata Singing

\begin{tabular}{|c|c|c|c|}
\hline Song Title & Lyric & Denotative Values & Connotative Values \\
\hline Ele rondo & $\begin{array}{l}\text { a) Ele rondo ou. Ou oh } \\
\text { e oh ou a ou oh ea } \\
\text { ngae. a o ai rondo } \\
\text { manga ne ae a, a a a } \\
\text { a a a a ae ae a. } \\
\text { b) a a ei, ei ei ei a ou o } \\
\text { ea ngae. zale wewo } \\
\text { ou mai. e e le ele } \\
\text { rondo o u, ou oh ea } \\
\text { ngae ee. }\end{array}$ & $\begin{array}{l}\text { a) Ele: though, rondo: } \\
\text { accusing, blaming. Rondo } \\
\text { can also be interpreted as } \\
\text { a warning or advice } \\
\text { (depending on the context } \\
\text { of the sentence used); ea } \\
\text { ngae: used to the beautify } \\
\text { song; manga: there is. } \\
\text { b) Zale wewo: accross; mai: } \\
\text { come here (come). }\end{array}$ & $\begin{array}{l}\text { a) Even though there are people who } \\
\text { accuse and blame us in any case, } \\
\text { we must not hate them, must } \\
\text { forgive them and be patient. In } \\
\text { matters related to customs, if we } \\
\text { make a mistake and get unpleasant } \\
\text { treatment from the family or the } \\
\text { surrounding community, we must } \\
\text { accept it gracefully because we } \\
\text { have violated the values or } \\
\text { provisions of applicable customary } \\
\text { law. Therefore, we cannot make } \\
\text { the same mistakes. }\end{array}$ \\
\hline
\end{tabular}

Table 2 Bomba Lau Mbata Singing

\begin{tabular}{|c|c|c|c|}
\hline Song Title & Lyric & Denotative Values & Connotative Values \\
\hline Bomba lau & $\begin{array}{l}\text { oh a oh o rame mo ou } \\
\text { ea ngae. oh tawa mo ou } \\
\text { ea ngae a. ae o rame } \\
\text { bomba lau. Oh ghele no } \\
\text { ao ae a, ae o rame lelo } \\
\text { kala ne. oh a oh tawa } \\
\text { mo ai e, woe mo ema ne. } \\
\text { oh ine reku lelu ma'e } \\
\text { rero ma'e ghewo oh oh } \\
\text { a o o o a o ea. Ou oh } \\
\text { ou oh ea oh ae ae a, ae } \\
\text { a oh ae, oh rame bomba } \\
\text { lau a oh ele a. }\end{array}$ & $\begin{array}{l}\text { oh a oh o: used to beautify the } \\
\text { song; rame: crowded; ea } \\
\text { ngae: used to beautify songs; } \\
\text { Bomba (name of one of the } \\
\text { ancestors); lau: there; lelo: } \\
\text { take a look; kala: forest; tawa: } \\
\text { laugh; woe: friend; ine: } \\
\text { mother; reku: } \\
\text { warning/affirmation; lelu: } \\
\text { thread. }\end{array}$ & $\begin{array}{l}\text { This song teaches children and } \\
\text { grandchildren to always remember } \\
\text { ancestors who have died and to } \\
\text { remember all the advice that had been } \\
\text { given by Opa Bomba that when a } \\
\text { mother gives advice, we must listen } \\
\text { and remember it. Remember forever } \\
\text { like thread that never breaks, so we can } \\
\text { pass on that advice to the next } \\
\text { generations. }\end{array}$ \\
\hline
\end{tabular}


Table 3 Toto Ro Mbata Singing

\begin{tabular}{|c|c|c|c|}
\hline Song Title & Lyric & Denotative Values & Connotative Values \\
\hline Toto ro & $\begin{array}{l}\text { e ei e e a manu ou toto } \\
\text { ro manu e e e a oh ea } \\
\text { ngae. ei ei e e e e e mata } \\
\text { mani toe jari a. ou ou } \\
\text { lawa a ei e. Oh oh, gheo } \\
\text { ghao lando. ao o ae a. } \\
\text { ae ae a oh ou ou manu } \\
\text { la e ne toto ro e. }\end{array}$ & $\begin{array}{l}\text { e ei e e a: used to beautify the } \\
\text { song; manu: chicken; toto: } \\
\text { with; ro: pedis; mata: died; } \\
\text { toe jari: no/no results; lawa: a } \\
\text { large group of people; gheo- } \\
\text { ghao: turning. }\end{array}$ & $\begin{array}{l}\text { This song teaches that we must respect } \\
\text { people who have died by offering } \\
\text { sacrifices in the form of chickens } \\
\text { together and it also teaches that we } \\
\text { must do something right in accordance } \\
\text { with applicable regulations (do not } \\
\text { deviate rules). }\end{array}$ \\
\hline
\end{tabular}

The value contained in the song is the values of obedience and patience. Obedience to the prevailing customary provisions and parents by listening to the advice given by fathers and mothers. While patience is about accepting ridicule or bad things said by people around. It also teaches people to respect those who have died.

Table 4 Rogho Sambi Mbata Singing

\begin{tabular}{|c|c|c|c|}
\hline Song Title & Lyric & Denotative Values & Connotative Values \\
\hline $\begin{array}{l}\text { Rogho } \\
\text { sambi }\end{array}$ & $\begin{array}{l}\text { a) Rogho sambi lau. Sambi } \\
\text { lau ao ou oh ea ngae. rame } \\
\text { rogho sambi ta lau. Oh lau } \\
\text { lau oh oh ba'e rogho sambi. } \\
\text { b) Rame sambi lau, sambi lau ao } \\
\text { oh ou oh ngae e a. Ema po } \\
\text { soro, ma'e rero ma'e ghewo } \\
\text { ta lau. }\end{array}$ & $\begin{array}{l}\text { Rogho: dry; sambi is a type } \\
\text { of tree; rame: crowded; lau: } \\
\text { there; Ba'e is interpreted as } \\
\text { an expression of mercy. } \\
\text { Ema: father; po: advice; } \\
\text { soro: order; ma'e: don't; } \\
\text { rero: obstruct; ghewo: } \\
\text { forget. }\end{array}$ & $\begin{array}{l}\text { a) It tells about the situation } \\
\text { in the village that is } \\
\text { experiencing drought due } \\
\text { to long drought, because } \\
\text { the people have made a } \\
\text { mistake, so beg for } \\
\text { mercy to God to provide } \\
\text { rainwater. } \\
\text { b) When fathers are giving } \\
\text { advice, let us listen (no } \\
\text { fuss) and not forget it. }\end{array}$ \\
\hline
\end{tabular}

The values contained in the third song (Rogho Sambi) are religious and educational values. Religious value is contained in the second song in part (a), where the song teaches us, that if we live in the world and experience bad things, we should pray and ask God to give something good in our lives. While the value of education is in section (b) stating that children must listen to the advice given by the father and must not forget the advice.

\section{2) Religious and Educational Values}

Religious values are sacred values related to the divine dimension in the activities of human life as servants of God on earth. The religious values contained in the second song (Rogho Sambi) will be explained as follows.

\section{3) Sociological and Educational Values}

Sociological values present relationships or interactions between humans, and those of humans in a society as reflected in the form of behavior, traits, and habits to build more harmonious reciprocal relationships. The sociological value contained in the third song, Wolo Lau, will be explained as follows. 
Table 5 Wolo Lau Mbata Singing

\begin{tabular}{|c|c|c|c|}
\hline Song Title & Lyric & Denotative Values & Connotative Values \\
\hline Wolo lau & $\begin{array}{l}\text { e ei e e e a kodo nara. } \\
\text { Oh ou lau wolo lau e. } \\
\text { Ea ngae a o o a o ea } \\
\text { ngae le e ei e e e e e } \\
e \text { e, ma'e rero ma'e } \\
\text { ghewo a. ou oh wolo } \\
\text { lau ei ei e e. Oh oh } \\
\text { ao o o rame nara, ae } \\
\text { ae a oh ou ou ou rame } \\
\text { nara lau ae ghewo } \\
\text { dhano e. }\end{array}$ & $\begin{array}{l}\text { e ei e e e a: used to } \\
\text { beautify a song; lau: } \\
\text { there; wolo: mountain; } \\
\text { ea ngae: used to beautify } \\
\text { the song; ma'e: don't; } \\
\text { rero: obstruct; ghewo: } \\
\text { forget; rame: crowded; } \\
\text { nara: brothers; dhano: } \\
\text { too. }\end{array}$ & $\begin{array}{l}\text { a) The meaning of the word } \\
\text { Mount is above, intended for a } \\
\text { leader (chief) meaning that } \\
\text { people in certain tribes should } \\
\text { respect the leader. } \\
\text { Communities and leaders have } \\
\text { a very close relationship and } \\
\text { interact with each other because } \\
\text { if the community experiences a } \\
\text { problem, especially in terms of } \\
\text { customs, they must } \\
\text { communicate with the leader } \\
\text { (the tribal chief). } \\
\text { b) Let us brothers together listen } \\
\text { to the advice given and not } \\
\text { forget the advice. }\end{array}$ \\
\hline
\end{tabular}

Sociological value obtained is the interaction between the leader (chief) and also the community. There is a reciprocal relationship and good communication between the tribal chief and the community. This teaches us that we must interact with each other in everyday life. While the value of education includes obedience, where children should listen and not forget the advice given by anyone, especially parents.

\section{Conclusions}

Penti ceremony is a ritual conducted to give thanks to Mori Ndewa or God and Embu Nusi (Ancestors) for the harvests that have been obtained by the community. As for its structure, it consists of some stages, namely Tete Ndere, Ndera, Pa'u Manu and Mbata (which are accompanied by singing). The form of singing used in Mbata at Penti ceremony is a solo, sung first by mori mbo (host) then sako (is answered) by the people involved and knows the songs in

the following order: Ele Rondo, Rogho Sambi/Kaju Sambi, Wolo Lau, Bomba Lau, and Toto Ro. From the aspect of function, the Mbata singing in Penti Ceremony functions as a means of ceremonies and rituals, as a means for accompanying dances and communication media, as a means of expressing themselves and public entertainment, as well as an educational tool for young generations. Whereas Mbata Song values contained are educational, religious, and sociological values.

\section{REFERENCES}

[1] Agus, Arnoldus Yansen, dkk "Ritual Penti Pada Masyarakat Desa Ndehes, Kecamatan Wae Ri’i, Kabupaten Manggarai, Flores, Nusa Tenggara timur.”, Universitas Udayana, Humanis: Journal of Arts and Humanities, 01-02-2018, DOI: https://doi.org/10.24843/JH.2018.v22.i01.p26

[2] Dahus, Fransiska. "Peran Upacara Penti Dalam Masyarakat Kabupaten Manggarai Timur”. Makalah Prodi Pendidikan Sejarah Universitas PGRI Yogyakarta (2017). URL: http://repository.upy.ac.id/1704/1/Artikel.pdf.

[3] Situmorang, Robinson. "Strategi Pembelajaran Berbasis Multiple Intelligence (MI) untuk Pencapaian Kompetensi dalam Pembelajaran." dalam Mozaik Teknologi Pendidikan, eds. Dewi Salma Prawiradilaga dan Eveline Siregar (Jakarta: Kencana, 2008), h 59 (2004).

[4] Greg Soetomo, S. J. Krisis Seni Krisis Kesadaran. Kanisius, (2003).

[5] Widjaja, H. A. W. "Komunikasi, komunikasi dan Hubungan Masyarakat", Jakarta: PT. Bumi Aksara (2008). 